Article

\title{
Upshots of Intrinsic Traits on Social Entrepreneurship Intentions among Young Business Graduates: An Investigation through Moderated-Mediation Model
}

\author{
Hameed Asghar Sana ${ }^{1}$, Salem Alkhalaf ${ }^{2}{ }^{(D}$, Salman Zulfiqar ${ }^{1, *} \mathbb{C}$, Waleed Mugahed Al-Rahmi ${ }^{3}{ }^{(1)}$, \\ Ahmad Samed Al-Adwan ${ }^{4}\left(\mathbb{D}\right.$ and Anas Ratib AlSoud ${ }^{4}(\mathbb{D}$ \\ 1 Department of Management Sciences, COMSATS University Islamabad, Sahiwal Campus, \\ Islamabad 44000, Pakistan; hameedsanagcc@gmail.com \\ 2 Department of Computer, College of Science and Arts in Ar Rass, Qassim University, \\ Ar Rass 1162, Saudi Arabia; s.alkhalaf@qu.edu.sa \\ 3 Computer Science Department, Community College, King Saud University, Riyadh 11437, Saudi Arabia; \\ waleed.alrahmi@yahoo.com \\ 4 Electronic Business and Commerce Department, Al Ahliyya Amman University Jordan, \\ Balqa Governorate 19328, Jordan; a.adwan@ammanu.edu.jo (A.S.A.-A.); a.alsoud@ammanu.edu.jo (A.R.A.) \\ * Correspondence: salmanzulfiqar@cuisahiwal.edu.pk
}

Citation: Sana, H.A.; Alkhalaf, S.; Zulfiqar, S.; Al-Rahmi, W.M.;

Al-Adwan, A.S.; AlSoud, A.R.

Upshots of Intrinsic Traits on Social Entrepreneurship Intentions among Young Business Graduates: An Investigation through Moderated-Mediation Model. Sustainability 2021, 13, 5192. https://doi.org/10.3390/su13095192

Academic Editors:

Carlos Lopez-Gutierrez,

Ana Fernandez-Laviada and

Andrea Pérez

Received: 25 March 2021

Accepted: 23 April 2021

Published: 6 May 2021

Publisher's Note: MDPI stays neutral with regard to jurisdictional claims in published maps and institutional affiliations.

Copyright: (c) 2021 by the authors. Licensee MDPI, Basel, Switzerland. This article is an open access article distributed under the terms and conditions of the Creative Commons Attribution (CC BY) license (https:// creativecommons.org/licenses/by/ $4.0 /)$.
Abstract: Social entrepreneurship has recently become a much-desired area of research for academia, practices, and policymaking. Natural or cognitive personal thoughtfulness like loving-kindness meditation (LKM) and compassion trigger individual intentions towards the social entrepreneurial venture. In this process of individual social entrepreneurial intention personality trait plays a very vital role, such as entrepreneurship resilience. For this study, a purposive sampling technique was incorporated and data was collected from 631 business and management sciences students. Data is analyzed by SPSS 23 and for the hypothesis testing, we used the bootstrap analysis of Hayes PROCESS v3.5. This study depicts that LKM has a positive significant impact on compassion and no significant impact on social entrepreneurship intentions while resilience strengthens the direct relationship of compassion with social entrepreneurship and the indirect relationship of LKM with social entrepreneurship via compassion. This study contributes to solving the economic and social problems over the globe especially by boosting the LKM and resilience traits so that the young graduate commence social entrepreneurship. This study helps the academician and policymakers to adopt strategies through which they can encourage youth to indulge in social entrepreneurial ventures solve the social problem and decrease unemployment.

Keywords: LKM; compassion; entrepreneurship resilience; social entrepreneurship

\section{Introduction}

Social entrepreneurship has become a very appealing and endeavoring area of research for the researchers and the community so that it paves the ways of business connections with social and collective issues to create aggregate and social value [1,2]. Social entrepreneurship has recently become a very desired area of research for practice, policymaking, and business academics [3]. Social entrepreneurship currently has obtained a lot of attention [4]. In recent years, the concept of social entrepreneurship has caught much attention of academics and professional practitioners, as shown by an increase in the size of theoretical literature and by the growth of new scientific and non-scientific communities [5]. The market or business approach to resolve the social issues of a particular community, social entrepreneurship has coupled with two distinct and noble targets; generating economic value and generating social value. In both social and economic domain, urgent need for establishing social entrepreneurship arise, through which the people solve the economic 
and social problems with the best characteristic of generating employment opportunities for an unemployed person of a particular community [6].

Social entrepreneurship is a meaningful process developed on the IIS of the base of institutional settings to fulfill emotional and social needs [7]. The collective and prosocial compassion-driven emotions triggered social entrepreneurship [8]. Many researchers set passion and compassion as a basic instigator of social entrepreneurship, which is emotional [1]. So, compassion has been recognized as a basic motivator towards social entrepreneurship rather than any other self-oriented motivations. Much of the existing research does not fully examine the factors that trigger social entrepreneurship, thus the factors that encourage social entrepreneurship still unexplored, which motivates the persons towards social entrepreneurship [9].

Research has been conducted with respect to different dimensions of social entrepreneurship like entrepreneurial intentions of students in social entrepreneurship [6], concerns of measuring social growth strategy in social entrepreneurship [10], opportunities for social entrepreneurship [7], social entrepreneurship present and past [11], social entrepreneurship for development peace and social development [6], social sense-making and social entrepreneurship [11], social base and social integration for social entrepreneurship [12], and in other different dimensions and factors, which affect the intentions towards the social entrepreneurship but the in this study we specifically discussing some personality traits, which boost the intentions towards the social entrepreneurship. These personality traits are loving-kindness meditation (LKM), compassion, and entrepreneurship resilience, these personality traits interact with each other in this study to enhance the social entrepreneurship intentions. This research is conducted to solve the following problem statement "which factors/personality traits trigger the intentions towards the social entrepreneurship".

This study is conducted to satisfy the following research questions. These research questions of this study are; what are the meditations being essential for the intentions of social entrepreneurship? What is the impact of LKM on compassion? What is the impact of compassion on intentions towards social entrepreneurship? Is compassion have a mediating role between the relationship of LKM and social entrepreneurship? It is also the important research question of this study that, what is the role of entrepreneurship resilience in the relationship of compassion and social entrepreneurship? Is compassion have any mediating role in the relation of LKM and social entrepreneurship? Is entrepreneurship resilience have a moderating role in the relation of compassion and social entrepreneurship? The above mentioned are the research questions, which have to be answered through this imperial study.

The objectives of this study are to explain the relation between LKM and compassion, to explain the relationship between compassion and social entrepreneurship, and to explain the relation between LKM and social entrepreneurship. It is also the objective of our study to find out the thought/meditation that a person must have, to develop the thinking about the formation of social entrepreneurship for the sake of economic and social objectives. Objectives of this study also include checking the mediating effect of compassion between the relationship of LKM and social entrepreneurship. The objectives of this study also include checking the conditional role (moderating role) of entrepreneurship resilience between the existing relationship of compassion and social entrepreneurship.

It is also the objective of the study is to explore the factors that trigger the intentions towards social entrepreneurship.

This study is conducted mainly to highlight the significance and impact of social entrepreneurship academically, and practice and for policy-makers. This study highlights the configuration of one's thoughtful meditation towards social entrepreneurship. This study also focuses on the personality trait that triggers them to establish social entrepreneurship. This study also distinguishes social entrepreneurship from other forms of entrepreneurship and undertakings. This study also highlights resilience, as a personality trait that strengthens the compassion and social entrepreneurship relation, more resilience more 
intentions of compassionate spirit towards social entrepreneurship, and less resilience week the intentions of compassionate spirit towards social entrepreneurship.

The factors that trigger the social entrepreneurship are the very rich area of study in the current era. In Pakistan, it is lacking to flourish social entrepreneurship practically and also academically. So, this empirical study focuses on the mediations, which enable the individuals towards social entrepreneurship. Moreover, there is a lacking of social entrepreneurship, which is based on collectivism, empathy, compassion, or LKM. The objective of this empirical study is to enhance the spirit of social entrepreneurship among the public especially among business students through the mediations of LKM, sympathy, compassion, and resilience.

Social entrepreneurship is helpful for social and economic problems. It helps reducing poverty, unemployment, and the shortage of certain goods or services [13]. The focus of this paper is to highlight that why people/students choosing social entrepreneurship as a profession and what kind of people/students choose this profession, it means what are the traits, feature, or emotions a person must have to adopt the social entrepreneurship as a profession. This study also critically state that our students are job seeker rather than job or opportunity creator. This study may contribute to solving the economic and social problems of the certain persons or society, which have the emotions of LKM and compassion. This empirical study also contributes theatrically in the literature of the world in the field of research, practice, and academia.

\subsection{Defining the Variables}

\subsubsection{Loving-Kindness Meditation (LKM)}

The classic LKM directs the individuals in different phases of thoughtfulness processes. Persons are guided to handle deep feelings of loving-kind toward the self, a peer, an unrelated person, a person having an adverse attitude, a group of persons working on one assignment, and finally about the whole world [14]. One of the major distinguishing features of the LKM is that it relies on emotional situations of loving and kindness regarding all stakeholders [5]. LKM focus on the development of pleasant social bindings with each other's and with the environment with the increasing dose of kindness, caring, and love emotions [14]. In real meaning, LKM implies a continuous process of thinking about happiness and healthiness of self, others and reducing self and others from sufferings regarding losses to self, others, and nature i.e., plants, animals, and planet [15].

\subsubsection{Compassion}

Compassion is an emotion through which the person is socially connected with others and wants to solve the issues of others [16] and crops warmth to the throbbing and wants of the others [17]. Compassion is one's explicit exhibition of the extensive consciousness of empathy towards others [17]. Observing others in soreness and distress, person might be an experience with compassion through which such person tries to minimize or remove the sufferings or pains of others [18]. The aspiration to prosocial enthusiasm, which is defined by Grant "the desire to expend effort to benefit other people". Precisely, compassion actions as the prosocial instigator, which works through the emotional association to help others that are in sufferings [14].

\subsubsection{Entrepreneurship Resilience}

Resilience may be defined as one's personal ability to handle negative or opposed conditions particularly when one facing experiencing a greater level of pressure, threat, or disturbance $[12,19]$. Entrepreneurial resilience is a personality behavior trait of a stable personality and it considered important for one's psychological regulations while facing up and down conditions during the process of entrepreneurship [20]. Entrepreneurship resilience determined the outcome and future of entrepreneurship. We may say that the future of entrepreneurship depends upon the entrepreneur's ability of resilience, how he or she overcome or handle the adverse or negative condition while entrepreneurship [16]. 
It comprises one's traits to utilize the resilience and show interests a readiness for future and current challenges faced by entrepreneurship [21]. It is also admitted in pursuing the resilience that individual's while in the process of running entrepreneurship he or she shows his personal commitment, psychological accomplishment, contentment, happiness, and enjoyment $[14,20]$. The steady and reliable intrinsic inspiration, which lies with individuals arise internally result in highly resilience in one's personality seem to be more committed and enthusiastic in the bitter and adverse situation [11].

\subsubsection{Social Entrepreneurship}

In the wider term, social entrepreneurship basically focusses on solving the social problems of the people intact with business activities, assist them in their activities, which may have multiple forms like cooperatives, credit unions, employees owned concerns, housing associations, community enterprise, and business development trusts [22,23]. Social entrepreneurship is a type of venture that is formed mainly to generate a positive influence on the society one on social well-being [24] and developing greater social values by helping great number of stakeholders in connection with specific objectives resolve some social issues [25]. The concept "social entrepreneurship" is derived from "commercial entrepreneurship", which means to focus on financial values instead of social values, which is the subject matter of social entrepreneurship [26].

Social entrepreneurship means gathering innovative means combining with resources to avail new opportunities to bring social change or to deal with social needs [3]. Ref. [27] suggest social entrepreneurship is very crucial and for worldwide prosperity and social welfare. Apparently, a social entrepreneur solves social issues, appearing as self-evident, based on his value judgment as an individual on the behalf or favor of another group of persons for their welfare and well-being. Social entrepreneurs grasp varying understandings about the sphere that they carry to bear in the contemplation of a specific social problem [28].

\section{Literature Review}

Social entrepreneurship is a unique form of entrepreneurship that is initiated by compassion, with a view to develop social entrepreneurship as caring entrepreneurs, this argument is based on the theory of ethics of care. Social entrepreneurship is a form of entrepreneurship, which is based on the theory of ethics of care [29]. While focusing on all the factors that motivate social entrepreneurship, this motivation the, ethics of care claimed as the essence for the formation of social entrepreneurship [13]. Social entrepreneurship means the entrepreneurial process to satisfy some social mission on the grounds of care for others because they realize the responsibility of taking care for others and giving them due care [30]. On these grounds, it may be stated that care ethics pursue the persons towards the social entrepreneurship. A social entrepreneur is a person who endorses himself for taking care of others to solve social problems of all the beneficiaries in certain communities or locations to maximize their social impacts [31].

The persons who have intentions towards social entrepreneurship focus his/her attention only on the care for others along with other objectives to use the resources, to start up the process, and how to manage the solutions to solve the problems of the society [6]. So, on the basis of above-mentioned arguments by different research, our research model was developed on the basis of ethics of care theory. It is also claimed that ethics of care has been formerly linked with feminism and justice, some of the theorists disagree with the justice part of ethics of care on the grounds that justice is an cognitive approach relating with the particular principles; rather care ethics concerned with moral alignment and care for others impartial to gender and justice [32]. The theorist of ethics of care [33] narrated an idea about care that females are more care oriented and males are more justice oriented. Caring implies empathy towards others and the actions of a person who is taking care is undertaken to fulfill the needs of others and tries to solve the problems of others [3]. 
Care is defined as, "Impact should not just be about serving more people-it should be about serving them well" [31]. Ethics of care is defined as the engagement of someone in a specific objective in order to make the world better by taking care of others regarding their needs based on emotional empathy and afterwards going through struggles to fulfill these needs [13]. The theory of ethics of care comprises four of its phases acknowledged by [3] in order to narrate care as a process of being passionate, caring about means the vigilance about the other's needs, taking care of means the responsiveness in connection with the other's needs, care giving means the struggle to fulfill the other's needs, and care receiving means listening to others, whether their need is actually fulfilled or not. The thing that is very interesting in these four phases of care is that the early two of the four phases is related to the state of emotions and the last two of the four phases is related to the practice. To argue in favor of ethics of care is the valuable framework developed by the in which compassion is recognized as the driver towards social entrepreneurship, so in light of the above arguments by the theorists [22] a researcher [13] about the theory of ethics of the care, our model was fully supported by this theory because our two prominent variables, i.e., LKM and compassion, are fulfilling the criteria of care, these two variables of our study are recognized as the drivers of social entrepreneurship. The model of this study was fully supported by the theory of ethics of care.

\subsection{Loving-Kindness Meditation (LKM) and Compassion}

LKM is considered the most valuable, effective, and active way to approach and improve compassion [34]. This is very much consistent with the theory of care ethics that a person who has care emotions will have care of others and will also act for the care and welfare of others [31]. Loving-kindness gradually reduces stress and biological stress [35]. Concerning mutual humanity, [11] states that LKM involvement increases community connectedness along with positive appraisals about self and others. Several studies are consistent with the result that loving-kindness enhances compassion [14,15]. It claimed in the study that LKM enhances the emotions of compassion for others as a prosocial behavior [36], it also promotes feelings related to compassion towards others to nature and the universe [15]. Ref. [14] in the paradigm of loving-kindness also emphasize that loving-kindness improves day-to-day experiences of helpful and encouraging emotions. The aspects of compassion and self-kindness are mostly affected by their caring and kindheartedness involvement [37]. Ref. [10] inspect using meta-analysis and systematic review that loving-kindness has a positive effect on compassion. Several studies claim that loving-kindness arouse the sympathy relevant system in the brain along with the sections of social cognition [14]. LKM proved to be the best way to attain compassion. With the help of the collected literature mentioned above, we might hypothesize:

\section{Hypothesis 1. LKM is directly related with compassion.}

\subsection{Compassion with Social Entrepreneurship}

Ref. [13] examine the role compassion played in the process of motivation people towards social entrepreneurship. While differentiating between entrepreneurship and social entrepreneurship, [27] states that social entrepreneurship mainly highlights a social mission, which may help in the elimination of poverty or solving social issues faced along with financial earnings; also distinct from those organizations that are purely focused on enhancing the shareholder's value. It is strongly claimed that compassion reverses the fundamental criteria for evaluation of entrepreneurship focusing on other or social bases along with aggressively misrepresenting someone's perceived efficacy, commitment towards creating the social value, and solving social issues $[9,27]$. In simple words, compassion develops a cognitive process that is motivated in generating accompaniments to traditional philosophies of entrepreneurship. Ref. [9] advocate about distinct inspirations, rather than commercial or self-profit motives, which stimulate the intentions towards the social entrepreneurship whereas [11] claimed that compassion produces outcomes in the way 
to forming the social undertaking, which satisfy their emotions regarding solving some particular social issues that exist in their community and finally give intentions towards the formation of social entrepreneurship. States that self-compassion triggers one's personal desire to help others especially in those times when other people or a community are in the process of serious sufferings or problems. Moreover compassion increases the prosocial behavior to eliminate the sufferings of other people to satisfy one's personal desire or emotions [6].

While focusing on motivational factors that stimulate the social entrepreneurship we cannot miss the main factor, compassion [38]. Compassion generates feeling to solve social problems or issues that are suffered by the community. Explicitly, we claim that compassion with the other direction and emotional linking act by way of a prosocial instigator of perceptive and affecting developments that are measured preconditions for activity of social entrepreneurship [27]. So, on the basis of the above logics and literature we assume that compassion encourages individuals to be involved in the process of social entrepreneurship. Compassion works as a stimulus for forming social entrepreneurship. On the basis of these arguments, we hypothesized that:

\section{Hypothesis 2. Compassion is directly related with social entrepreneurship.}

\subsection{Loving-Kindness Meditation (LKM) and Social Entrepreneurship}

Many social entrepreneurship researchers posit that LKM is a major driver of social entrepreneurial performance. LKM focus on improvement of pleasurable social ties with each other's and with the atmosphere with the increasing prescription of kindness, helpful, and love emotions [39]. LKM implies a continuous process of thinking about happiness and healthiness of self and others and reducing self and others from sorrows regarding self, others, and nature (plant, animals, and planet) without any discrimination [15]. Keeping in view the background of the social entrepreneurship, individual's general emotions towards general kindness remains the key factor through which such individuals group the other persons, which derive from some social and financial requirements. LKM recognized as an antecedent towards social entrepreneurship [23,40]. The person who have the thoughts like love and kindness towards others especially in the situation in which other people or community are in sufferings or pains then they motivate to take some sustainable decisions towards the social entrepreneurship [40]. Caring is one of the individual traits of a person that motivate that individual to resolve the economic and social issues of others by stepping towards the formation of such an enterprise through which such an individual feels satisfaction and satisfies their thirst for caring [13].

In an additional investigation regarding social entrepreneurship programs, researchers also establish that LKM remained constrained in the practices of social entrepreneurship [14,27]. This study proposes that LKM for individuals in wide-ranging encouraging/stimulating sufficient intentions towards the development of social entrepreneurial intentions. To satisfy one's prosocial inspirations, to solve the particular social issues, and to synthesize his intentions a social entrepreneur may use their LKM as a stroke with a particular group of disregarded persons. To provoke LKM with the distress of that specific community and promote social entrepreneurship. On the basis of above debate, we could develop such a hypothesis:

\section{Hypothesis 3. LKM is directly related with social entrepreneurship.}

\subsection{Compassion Mediates the Relation between LKM and Social Entrepreneurship}

Compassion severely defined as the expressive and emotional response of kindness for nature, all beings, others, and self with an emotional desire to improve suffering [41]. Empirical research findings are powerfully reassuring of this logic, presentation that compassion reliably facilitates LKM, feelings, and behaviors [29]. For illustration, [34] catch 
that compassion may be nurtured with LKM training and suggestions linking this with humane behavior.

In recent, [15] presented that LKM goes outside social relatedness, it also goes to the gradual development of compassion meditations in the LKM practices. We theorized that compassion emotions definitely link with LKM to social entrepreneurship. While in the process of establishing social entrepreneurship, compassion acts as a prosocial and sympathetic integrative thoughtfulness intermediary and assurance to improving suffering of others. We became to theorize because of the close by communication between kindness emotions and social entrepreneurship along with sustainable environmental entrepreneurship that it can be addressed through compassion [34].

\subsection{Entrepreneurship Resilience Moderates the Relation between Compassion and Social Entrepreneurship}

Resilience is about the person's ability to adjust well to negative conditions, particularly when such a person is facing extraordinary stages of strain, threat, trauma, or stress [42]. Entrepreneurship resilience is very much related with the entrepreneurship especially with the social entrepreneurship just because of two reasons; one is that most of the scholars considered the resilience as a combination of individual traits like self-efficacy, tenacity, readiness, and hardiness to clarify how some of the entrepreneurs are successful in their entrepreneurships if they have such resilience traits rather than those entrepreneurs who have less resilience traits are less successful in the field of entrepreneurships; the second reason is that behavior and cognitive entrepreneurial capabilities for the unique form of entrepreneurship just like the social entrepreneurship has more potential to meet/handle the situations to adjust with and to perform the social entrepreneurship responsibilities for a longer period of time through his resilience traits [14].

In broader speaking, care ethics defined as "a species of activity that includes everything we do to maintain, contain, and repair our 'world' so that we can live in it as well as possible" [43]. So, on this basis of the theory, the persons who have more resilience can practically put in more efforts for serving the people well because such a resilient person has more energy and enthusiasm to serve the society. The theory of ethics of care comprises four of its phases acknowledged by [22] in order to narrate care as a process of being passionate, caring about means the vigilance about the other's needs, taking caring of means the responsiveness in connection with the other's needs, care giving means a struggle to fulfill the other's needs, and care receiving means listening to others, whether their need is actually fulfilled or not. The thing that is very interesting in these four phases of care is that the early two of the four phases are related to the state of emotions and the last two of the four phases are related to the practice. So, on the basis of last two phases of the theory of care of ethics, which is related to the practice, these last two phases are directly related to the resilience quality of the person regarding solving the social and economic problems of the society. More resilience in such a person will result in more care practically and less resilience will result in less care practically. To argue in favor of ethics of care is the valuable framework developed by the [5] in which compassion is recognized as the driver towards social entrepreneurship about the theory of ethics of the care, our moderator, i.e., entrepreneurship resilience, is fully supported by this theory on the grounds that entrepreneurship resilience has a conditional effect on this model and a moderating effect in a direct relationship between compassion with social entrepreneurship and also an indirect relationship between LKM with social entrepreneurship via compassion.

More resilience predicted more self-entrepreneurship and less resilience predicted less self-entrepreneurship [44]. With the effects of entrepreneurship resilience on the direct relationship of compassion with social entrepreneurship being stronger in the case of a person that is more resilient and these special effects weaker in the case of a person that is less resilient. With these special effects of entrepreneurship resilience on the indirect effect of compassion in the relationship of LKM with social entrepreneurship being stronger in the case of a person that is more resilient and these special effects weaker in the case of a person that is found less resilient. Further it is assumed that under a situation when a 
person has a high degree of entrepreneurship resilience it will enhance the levels of social entrepreneurial interests and readiness for social entrepreneurial challenges, and under the situation when a person has a low degree of entrepreneurship resilience it will lower the levels of social entrepreneurial interests and less readiness for social entrepreneurial challenges. Thus, we hypothesized that:

Hypothesis 4. Entrepreneurial resilience moderates the direct relationship between compassion with social entrepreneurship.

Hypothesis 5. Entrepreneurial resilience moderates the indirect relationship between LKM with social entrepreneurship via compassion.

All the hypothesis are shown in the theoretical model depicted in Figure 1.

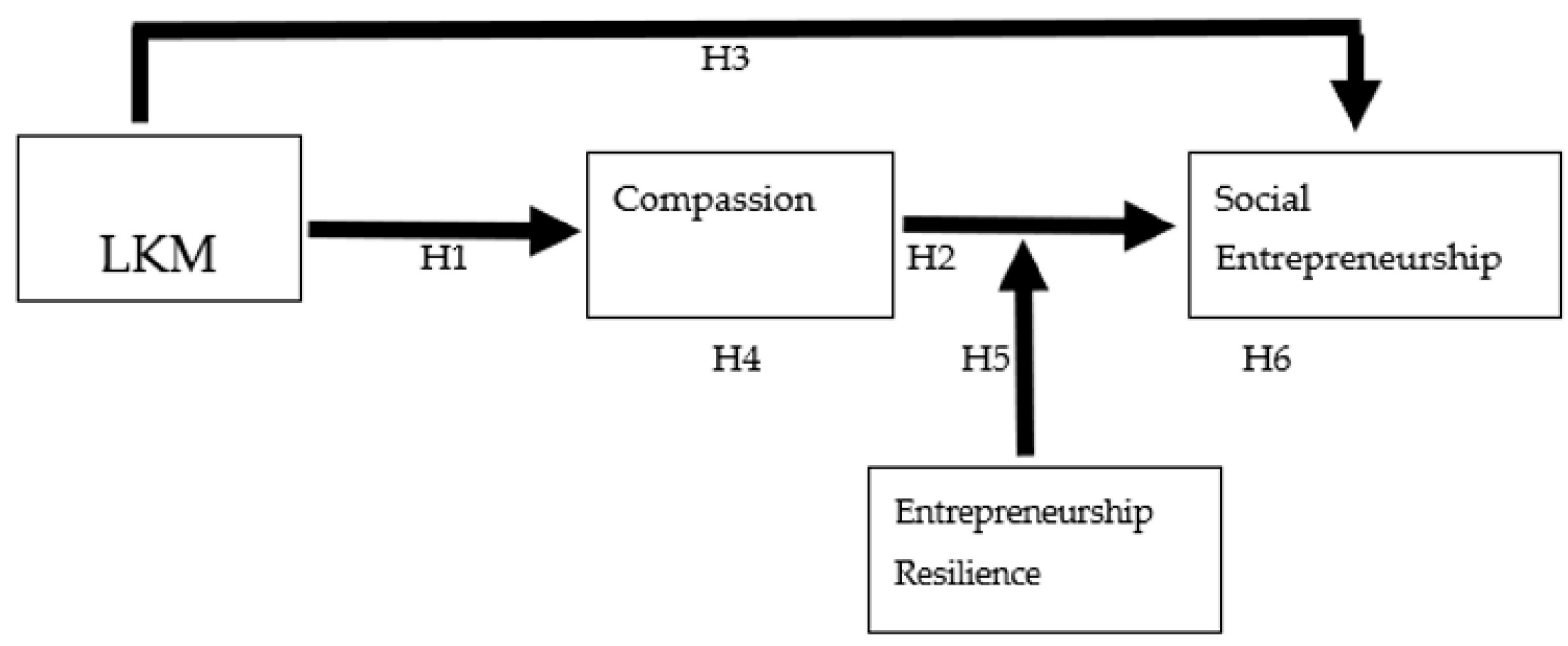

Figure 1. Theoretical model.

\section{Research Methodology}

This paper provides insights for the positivism and deductive approach. The survey questionnaire was used for data collection by using the non-probability sampling technique. The non-probability convenience sampling technique was used to select the samples. The model in this study was tested on a sample of Pakistani students in the field of business and management studies, which is persistent as per the studies of [45] in which 300 students are selected from the universities of Turkey to test the empirically study for support the proposed model regarding intentions of entrepreneurship [6]. Such model research represents the specific contextual factors that are relating with the young person's social entrepreneurship intentions. There are also some other examples of such models in which entrepreneurship/social entrepreneurship data is collected through the samples of institution of higher education students in Kenya by [46]. This study was based on the "person-entrepreneurship fit" model, which was suggested primarily in "2006 by Mair and Noboa" in which firstly explored the antecedents of students' social entrepreneurship intentions [6]. "Mair and Noboa's model" is also established on "Ajzen's theory of planned behavior", which suggests that social entrepreneurship intentions arise from four human personality traits such as empathy, moral judgment, a proxy for social norms, and attitude towards the behavior of others; Hockerts in 2016 also used this model in his study regarding social organizations and antecedents of social entrepreneurship intentions in which students are chosen as a sample for investigation [6]. Data were collected from the business and management sciences students belonging from different universities of HEC recognized from different cities of the Punjab province. Due to COVID-19, an online questionnaire was distributed through google forms among the students of the 
above mentioned cities, in total 900 questionnaires were distributed among students with the assistance of their teachers at time lag 1 . Out of which we received 587 completely filled questionnaire with the response rate of $65.22 \%$. In the second time lag survey it was circulated only to the 587 students who correctly responded in first phase, and in total 463 completed questionnaires were returned, with the response rate of $78.87 \%$. A total of 430 questionnaires were also distributed traditionally among the students of the above mentioned cities, with the assistance of their teachers at time lag 1 . Out of which we received 310 completely filled questionnaires with the response rate of $72.09 \%$. The second time lag survey was circulated only to the 310 students who correctly responded in first phase, and in total 276 completed questionnaires were returned, with the response rate of $89.09 \%$. Respondents included both male and female students who were students of BBA, MBA, and MS business and management sciences. Total online responses of 463 and traditionally collected responses of 261 were analyzed then 93 responses were discarded due to incompletion then we had a final sample size of 631 for empirical analysis.

\subsection{Research Instruments}

In this survey, we collected data through a written questionnaire. Using a 5-point Likert scale from SD (strongly disagree, very low extent) to SA (strongly agree, very high extent). At time lag-1, we collected data on LKM and compassion. At time lag-2, we collected data on entrepreneurship resilience and social entrepreneurship. The purpose of collecting the data in two time lags is to reduce the biasness of the respondent. Cross sectional data was used for this study, which was collected in two time lags to avoid biasness of the respondent.

\subsubsection{LKM}

This scale of LKM comprises of four items through which respondents expressed their thoughtfulness regarding love, kindness, and sympathy [47]. It is specified that [47] has developed the scale of LKM. The scale of LKM is developed for the particular study conducted by [47]. In this scale the following items are included: "I always help people or animals in difficulty"; "I do not with the intention of hurting anyone's feelings."; "If I cannot help people in difficulty I would find ways for others to help"; and "If I do not have kind words to say, I say nothing". This scale had a Cronbach alpha of 0.862 . Average extracted variance (AVE) was 0.663 .

\subsubsection{Compassion}

We used a scale of compassion used by [48]. This scale has the 5-items such as: "I am a very compassionate person"; "I often notice people who need help"; "When I see someone hurt or in need, I feel a powerful urge to take care of them"; "It's important to take care of people who are vulnerable"; and "Taking care of others gives me a warm feeling inside". The Cronbach alpha for this scale of compassion was 0.897. Average extracted variance (AVE) was 0.696.

\subsubsection{Entrepreneurship Resilience}

For measuring the entrepreneurship resilience, we adopted the scale developed by [49]. This scale has the four items. The items of this scale are: "I look for creative ways to alter difficult situations."; "Regardless of what happens to me, I believe I can control my reaction to it"; "I believe I can grow in positive ways by dealing with difficult situations"; and "I actively look for ways to replace the losses I encounter in life". The Cronbach alpha for this scale of entrepreneurship was 0.812. Average extracted variance (AVE) was 0.516.

\subsubsection{Social Entrepreneurship}

To measure the social entrepreneurship we adopted a scale used by [33]. This scale has the five items. The items of this scale are: "Management are concerned about employees' problems"; "There is management commitment to the surrounding social problems"; 
"When evaluating the different methodologies necessary to address a problem, their social benefits are taken into account"; "When defining the objectives of the company, not all have an economic component, some have a social character" and "The company seeks information on business projects that, at the same time, can have a social benefit". The Cronbach alpha for this scale of social entrepreneurship was 0.867. Average extracted variance (AVE) was 0.592.

\section{Results and Findings}

\subsection{Demographics of the Respondents}

Respondents include both male and female students who were students of BBA, MBA, and MS business and management sciences. The total online responses of 463 and traditionally collected responses of 261 were analyzed then 93 responses were discarded due to incompletion then we had a final sample size of 631 for empirical analysis as mentioned in Table 1 and depicted in Figure 2 Age of the respondents are shown in Table 2 and depicted in Figure 3.

Table 1. Gender of respondents.

\begin{tabular}{cccc}
\hline Gender & Frequency & Percent & Cumulative Percent \\
\hline Male & 415 & 65.8 & 65.8 \\
Female & 216 & 34.2 & 100.0 \\
Total & 631 & 100.0 & \\
\hline
\end{tabular}

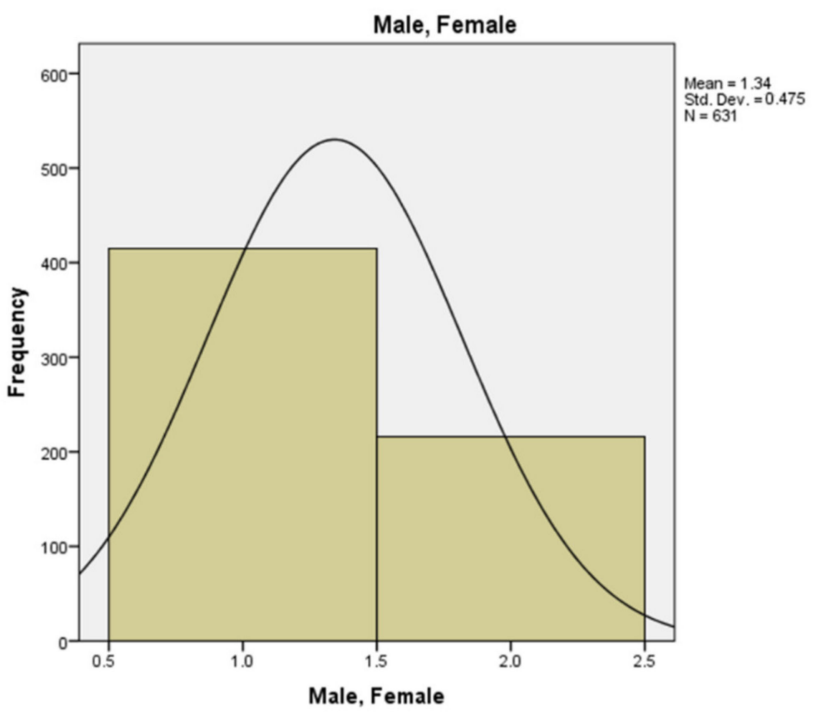

Figure 2. Gender of respondents.

Table 2. Age of respondents.

\begin{tabular}{cccc}
\hline Age & Frequency & Percent & Cumulative Percent \\
\hline below 22 & 121 & $19 . .1$ & 19.2 \\
22-24 & 278 & 44.1 & 63.2 \\
above 24 & 232 & 36.8 & 100.0 \\
Total & 631 & 100.0 & \\
\hline
\end{tabular}




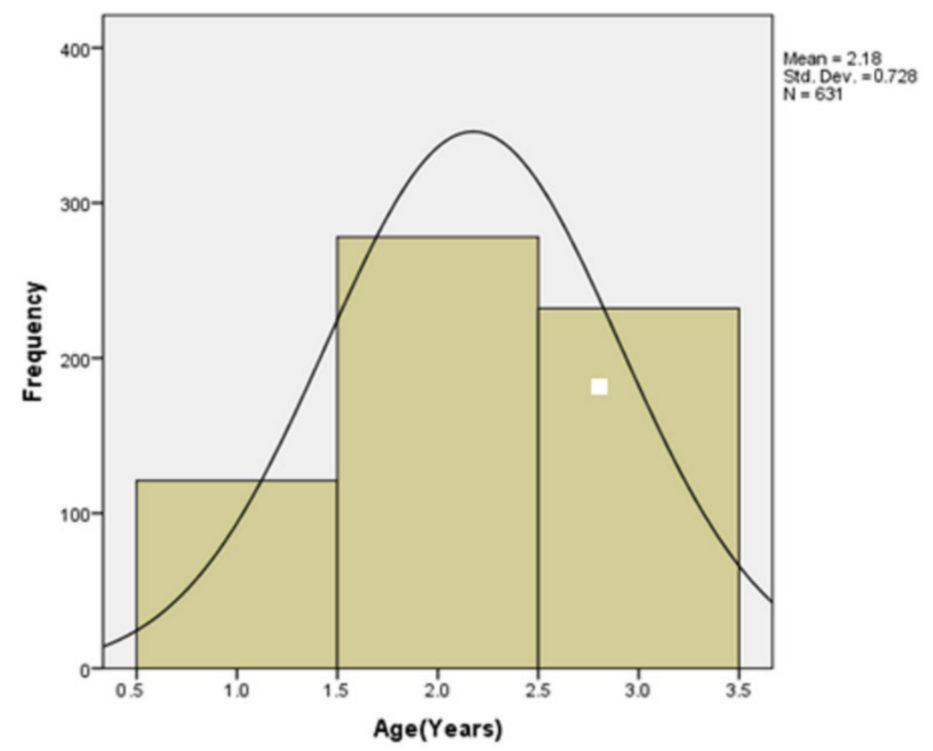

Figure 3. Age of respondents.

\subsection{Reliability Analysis}

Cronbach's alpha is the most widely used device to measure reliability. If the value of Cronbach's alphas is more than the 0.7 then it is acceptable and a value less than 0.7 will not be acceptable. All the variables of this study had a Cronbach's alpha more than 0.7, which means that data were reliable as shown in the Table 3.

Table 3. Cronbach's alpha.

\begin{tabular}{ccc}
\hline Sr. No. & Variables & Cronbach's Alpha \\
\hline 1 & LKM & 0.862 \\
2 & Compassion & 0.897 \\
3 & Entrepreneurship Resilience & 0.812 \\
4 & Social Entrepreneurship & 0.867 \\
\hline
\end{tabular}

\subsection{Normality Analysis}

The values of skewness in the model of this study were all less than +1 and greater than -1 , and the values were $\mathrm{LKM}=-0.772$, compassion $=-0.837$, entrepreneurship resilience $=-0.226$, and social entrepreneurship $=-0.118$, which are given in the Table 4 , which shows that the data were normally skewed. The values of kurtosis in the model of this study were all less than +1 and greater than -1 , and the values were LKM $=-0.201$, compassion $=-0.390$, entrepreneurship resilience $=-0.877$, and social entrepreneurship $=-0.873$, which are given in the Table 4 which shows that the data were normal.

Table 4. Normality analysis.

\begin{tabular}{ccccc}
\hline Variables & LKM & Self-Compassion & $\begin{array}{c}\text { Entrepreneurship } \\
\text { Resilience }\end{array}$ & $\begin{array}{c}\text { Social } \\
\text { Entrepreneurship }\end{array}$ \\
\hline Skewness & -0.772 & -0.837 & -0.226 & 0.181 \\
S. Error Skewness & 0.097 & 0.097 & 0.097 & 0.097 \\
Kurtosis & -0.201 & -0.390 & -0.877 & -0.873 \\
S. Error Kurtosis & 0.194 & 0.194 & 0.194 & 0.194 \\
\hline
\end{tabular}




\subsection{Descriptive Statistics}

The results of descriptive statistics for all variables have been given in Table 5. Since, we used the five points Likert scale in this study to collect data, if the mean value for any variable lies above 3 then it means that respondents perceived it as above average.

Table 5. Descriptive statistics.

\begin{tabular}{ccccccc}
\hline Sr. & Construct & Mean & SD & $\boldsymbol{t}$-Value & Df & Sig. (2-Tailed) \\
\hline 1 & Loving-Kindness & 3.7183 & 0.99900 & 93.496 & 630 & 0.000 \\
2 & Meditation & 3.5284 & 1.11580 & 79.433 & 630 & 0.000 \\
3 & Compassion & 3.5685 & 0.91848 & 97.597 & 630 & 0.000 \\
4 & Entrepreneurship & Resilience & 3.2041 & 0.97018 & 82.960 & 630 \\
\hline
\end{tabular}

The mean value for all variables is given in Table 5 and we can see that the mean value of LKM, compassion, entrepreneurship resilience, and social entrepreneurship was more than 3 thus we could say that these variables were satisfactory. As per Table 5 given below, the mean was more than 3 , which depicts that third option regarding the question that was selected by the respondents in our 5-point Likert scale.

\subsection{Confirmatory Factor Analysis (CFA)}

\subsubsection{Model Fitness Summary for CFA}

The multiple categories of indices are usually used for measuring the goodness fit of model and their resulted values along with their accepted criterion values are given in the table. Ref. [50] recommended the use of absolute fit indices such as root mean square error of approximation (RMSEA), CMIN/df, normed fit index (NFI), comparative fit index (CFI), Tucker Lewis index (TLI), goodness fit index (GFI), adjusted goodness fit index (AGFI), and informed fit index (IFI) for determining the fitness of the model. As we can see in Table 6 all measured values now showed consistent results as per with the recommended values or criterion [50]. The results depict that the RMSEA value was 0.055 (acceptable value $<0.08$ ), $\mathrm{CMIN} / \mathrm{df}$ value was 2.884 (acceptable value $<5.00$ ), NFI value was 0.957 (acceptable value $>0.90$ ), CFI value was 0.971 (acceptable value $>0.90$ ), TLI value was 0.957 (acceptable value $>0.90$ ), GFI value was 0.953 (acceptable value $>0.90$ ), AGFI value was 0.921 (acceptable value $>0.90$ ), and IFI value was 0.972 (acceptable value $>0.90$ ), and we could conclude that our measurement model were acceptable. All the values given in the Table 6 were in the normal acceptable range as the threshold values are given beside it. We say that the model was fit for this empirical analysis.

Table 6. Model fitness analysis.

\begin{tabular}{cccc}
\hline Sr. No. & Measures & Estimated Value & Default Value \\
\hline 1 & Root Mean Square Error of & 0.055 & $<0.08$ \\
2 & Approximation & 2.884 & $<5.00$ \\
3 & CMIN/df & 0.957 & $>0.90$ \\
4 & Normed Fit Index & 0.971 & $>0.90$ \\
5 & Comparative Fit Index & 0.957 & $>0.90$ \\
6 & Tucker Lewis Index & 0.953 & $>0.90$ \\
7 & Goodness Fit Index & 0.921 & $>0.90$ \\
8 & Adjusted Goodness Fit Index & 0.972 & $>0.90$ \\
\hline
\end{tabular}




\subsubsection{Validity}

Convergent Validity

For testing the convergent validity of the instrument, the average variance extracted AVE and composite reliability was adopted and the results suggested that all indices values were above 0.5 showing good convergent validity for the instrument [50]. According to [50], the AVE values should be greater than 0.5 to show good convergent validity. Tables $7-10$ show that all the values were according to the standard criterion and showing good convergent validity for our model. Figure 4 is the pictorial view of the measurement model.

Table 7. Factor loadings and AVE value LKM.

\begin{tabular}{ccc}
\hline LKM & Factor Loading & AVE \\
\hline LKM1 & 0.82 & 0.663 \\
LKM2 & 0.79 & \\
LKM3 & 0.81 & \\
LKM4 & 0.83 & \\
\hline
\end{tabular}

Table 8. Factor loadings and AVE value SC.

\begin{tabular}{ccc}
\hline SC & Factor Loading & AVE \\
\hline SC1 & 0.90 & 0.696 \\
SC2 & 0.83 & \\
SC3 & 0.83 & \\
SC4 & 0.74 & \\
SC5 & 0.87 & \\
\hline
\end{tabular}

Table 9. Factor loadings and AVE value ER.

\begin{tabular}{ccc}
\hline ER & Factor Loading & AVE \\
\hline ER1 & 0.79 & 0.516 \\
ER2 & 0.65 & \\
ER3 & 0.69 & \\
ER4 & 0.74 & \\
\hline
\end{tabular}

Table 10. Factor loadings and AVE value SE.

\begin{tabular}{ccc}
\hline SE & Factor Loading & AVE \\
\hline SE1 & 0.75 & 0.592 \\
SE2 & 0.70 & \\
SE3 & 0.69 & \\
SE4 & 0.82 & \\
SE5 & 0.87 & \\
\hline
\end{tabular}

Discriminant Validity

Discriminant values suggested how much difference was between the factors to determine the variance in the constructs. It was taken from the square root of AVE. Results in Table 11 also confirmed that the square root values of AVE were higher than all the correlations among constructs, thus confirming the convergent validity in our data. Table 11 shows that values measured and results suggested that all values were satisfactory, thus ensuring the discriminant validity of our instrument. The values of AVE under root or diagonal values were more than any correlation exists vertically or horizontally among the variables. 


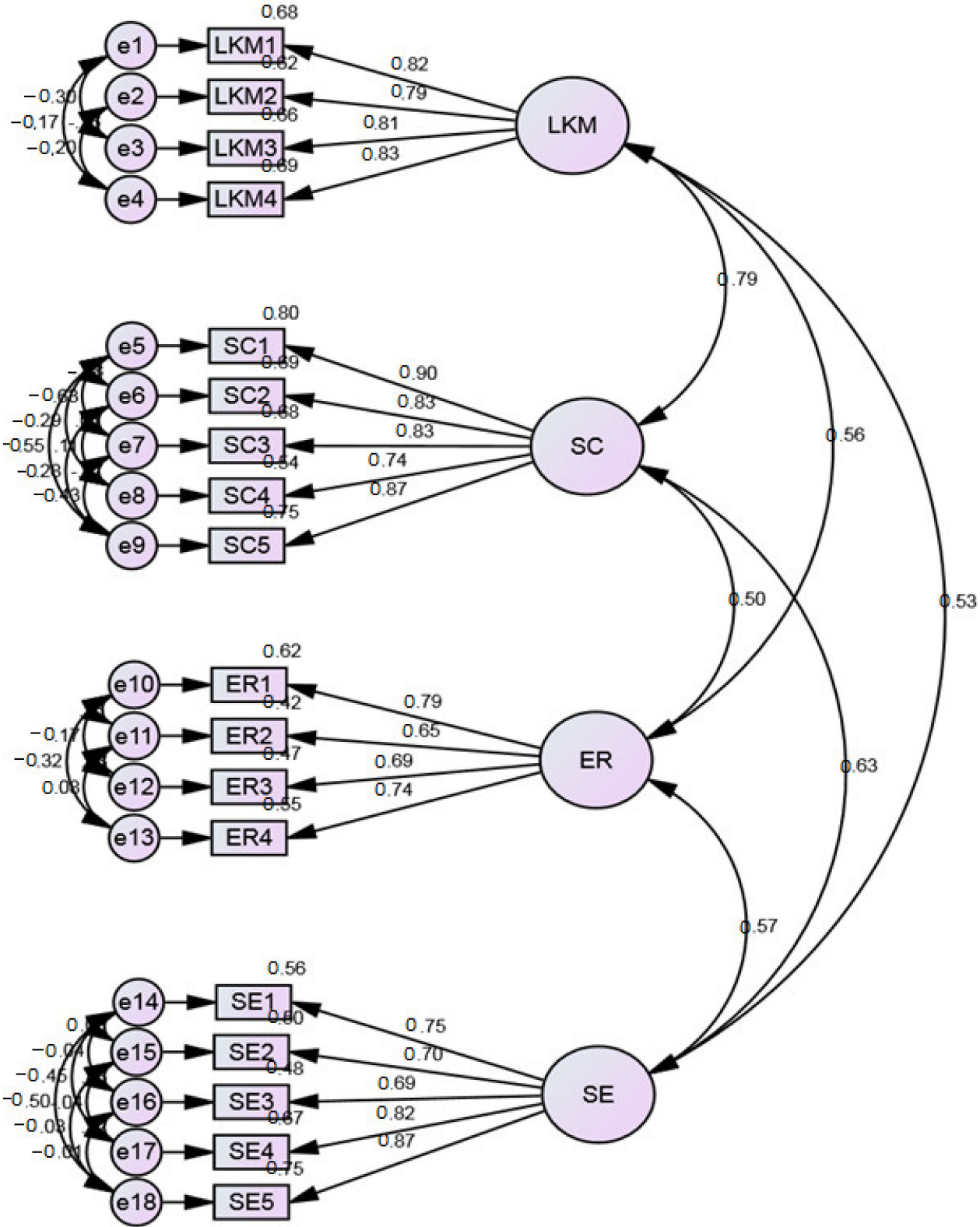

Figure 4. Measurement model.

Table 11. Scale correlation $\sqrt{ }$ AVE.

\begin{tabular}{ccccc}
\hline Variable & ER & LKM & SE & SC \\
\hline ER & 0.718 & & & \\
LKM & 0.559 & 0.814 & & \\
SE & 0.568 & 0.534 & 0.769 & 0.834 \\
SC & 0.505 & 0.787 & 0.635 & 0 \\
\hline
\end{tabular}

\subsection{Inter Items Correlation Matrix}

All the measures that were used in this study exhibited adequate reliability mentioned in the methodology and analysis part of the paper. Table 12 depicts that LKM shows a positive correlation with compassion $\left(0.747^{* *}\right)$, which was significant and had a strong correlation, this table also shows that compassion shows a positive correlation with social entrepreneurship $\left(0.585^{* *}\right)$, which was significant and had a moderate relationship, this table also show that LKM had a positive correlation with social entrepreneurship $\left(0.487^{* *}\right)$ that was significant but with a moderate relationship, this table also shows a positive 
correlation of LKM with entrepreneurship resilience $(0.492 *)$ that was significant but with a moderate relationship, this table also shows a positive correlation of compassion with entrepreneurship resilience $\left(0.438^{* *}\right)$ that was significant but with a moderate relationship, and also shows that resilience had a positive correlation with social entrepreneurship $\left(0.501^{* *}\right)$ that was significant but with a moderate relationship.

Table 12. Inter items correlation matrix.

\begin{tabular}{|c|c|c|c|c|}
\hline & LKM & Compassion & $\begin{array}{l}\text { Entrepreneurship } \\
\text { Resilience }\end{array}$ & $\begin{array}{c}\text { Social } \\
\text { Entrepreneurship }\end{array}$ \\
\hline LKM & 1 & & & \\
\hline Compassion & 0.747 & 1 & & \\
\hline $\begin{array}{l}\text { Entrepreneurship } \\
\text { Resilience }\end{array}$ & 0.492 & 0.438 & 1 & \\
\hline Social entrepreneurship & 0.487 & 0.585 & 0.504 & 1 \\
\hline
\end{tabular}

\subsection{Testing of the Hypothesis}

When further analysis was conducted that depicted that LKM had a significant positive relationship with compassion $(\beta=0.834 ; p<0.001)$, hypothesis 1 of a direct positive relationship between LKM and compassion was supported, and on the other side compassion showed a significant positive relationship with the social entrepreneurship intentions ( $\beta=0.425 ; p<001)$, so hypothesis 2 of a direct positive relationship between compassion and social entrepreneurship was also supported. It also was depicted in Table 13 that LKM had an insignificant positive relationship with the social entrepreneurship ( $\beta=0.033$; $p>0.01$ ), so hypothesis 3 of a direct positive relationship between LKM and social entrepreneurship intentions were not supported. First two direct relationship hypotheses of the model of this study were accepted but the third hypothesis of the direct relationship was rejected.

Table 13. Mediation and moderated mediation analysis.

\begin{tabular}{|c|c|c|c|c|c|c|}
\hline \multicolumn{7}{|c|}{ Social Entrepreneurship } \\
\hline & B & SE & LLCI & ULCI & $\mathbf{P}$ & $\mathbf{R}^{2}$ \\
\hline \multicolumn{7}{|l|}{ Direct Effects } \\
\hline LKM & 0.834 & 0.032 & 0.772 & 0.897 & 0.000 & 0.558 \\
\hline Compassion & 0.425 & 0.042 & 0.341 & 0.508 & 0.000 & \\
\hline Entrepreneurial Resilience & 0.282 & 0.036 & 0.211 & 0.353 & 0.000 & 0.429 \\
\hline $\begin{array}{l}\text { Entrepreneurial Resilience } \\
{ }^{*} \text { Compassion (Interaction) }\end{array}$ & 0.112 & 0.030 & 0.053 & 0.172 & 0.000 & \\
\hline \multicolumn{7}{|l|}{ Indirect Effects } \\
\hline $\mathrm{LKM} \rightarrow \mathrm{SE}$ (direct effect) & 0.033 & 0.050 & -0.066 & 0.132 & 0.512 & \\
\hline $\mathrm{LKM} \rightarrow \mathrm{SC} \rightarrow \mathrm{SE}$ & 0.3641 & 0.0383 & 0.2901 & 0.4403 & 0.000 & \\
\hline \multicolumn{7}{|l|}{ Conditional Indirect Effects } \\
\hline$-1 \mathrm{SD}$ & 0.268 & 0.039 & 0.193 & 0.345 & & \\
\hline Mean & 0.354 & 0.036 & 0.283 & 0.426 & & \\
\hline$+1 \mathrm{SD}$ & 0.440 & 0.047 & 0.350 & 0.535 & & \\
\hline
\end{tabular}

\subsection{Mediation Analysis}

For the purpose of testing hypothesis 6 of the study, the mediation effect of compassion between LKM and social entrepreneurship, we employed the "two-step approach as suggested by Preacher, Rucker, and Hayes (2007)". Through this two-step approach first of all we tested the significant relationship between the independent variable and mediating variable (IV $\rightarrow$ Med), then we tested the significant relationship between the mediating variable and dependent variable (Med $\rightarrow \mathrm{DV}$ ). Both these relationships were narrated in our hypothesis 1 and 2 and both these hypotheses were accepted in the previous part of the 
analysis. Now we went further for testing the mediation role of compassion between the direct relationship of LKM and social entrepreneurship intentions. The results are depicted in Table 13 showing that the direct relationship between LKM had an insignificant positive relationship with social entrepreneurship $(\beta=0.033 ; p>0.01)$ and an indirect relationship between LKM and social entrepreneurship via compassion $(\beta=0.3641 ; p>0.01)$ was significant, so we accepted hypothesis 6 of the mediating role of compassion between the relationship between LMK and social entrepreneurship. With the rejection of hypothesis 3 of the direct relationship of LKM with social entrepreneurship and this relationship becoming significant for these two variables via mediation of compassion, showing the full mediation. Consequently, we accepted hypothesis 6.

Hypothesis 6. Compassion mediates the relationship between LKM and Social entrepreneurship.

\subsection{Moderated Mediation Analysis}

In this section of the moderated mediation analysis, firstly we tested the moderating role of entrepreneurship resilience on the direct relationship between compassion and social entrepreneurship, as suggested in hypothesis 4 . The outcomes of the moderation analysis depicted in Table 13 displays that the interaction term (compassion $\times$ entrepreneurship resilience) had a significant impact on social entrepreneurship intentions $(\beta=0.112 ; p<0.01)$. To establish the direction of the supported significant interaction effect of compassion and entrepreneurship resilience, we scrutinized the interaction impact (compassion and entrepreneurship resilience) in the graph (see Figure 1). This graph disclosed that the positive association between compassion and social entrepreneurship was stronger when relative entrepreneurship resilience was at a high level and the positive association between compassion and social entrepreneurship was weaker when relative entrepreneurship resilience was at a low level. Therefore, hypothesis 4 of our model was supported and duly accepted.

After testing and accepting the moderating role of entrepreneurship resilience on the direct relationship between compassion and social entrepreneurship, as was hypothesized in hypothesis 4, we continued to test for hypothesis 5 for the conditional indirect impact of LKM on social entrepreneurship intentions via compassion. As in compliance of the studies reported by [44] and [51].We also used "PROCESS macro for SPSS (Hayes, 2012) to test moderated mediation", employing this model through which moderator affects the subsequent stage of the (Med $\rightarrow$ DV) mediation relationship (DV $\rightarrow$ Med $\rightarrow$ DV). The bootstrapping result as shown in Table 11 recognized three designated levels of comparative entrepreneurship resilience for instance ( $-1 \mathrm{SD}$, mean SD, and $+1 \mathrm{SD})$. These bootstrapping results support that the conditional indirect effect of LKM with social entrepreneurship intentions via compassion increases with the high level of entrepreneurship resilience and this indirect effect of LKM with social entrepreneurship intentions via compassion decreases with the low level of entrepreneurship resilience. These empirical results in a more specific form reflect that the positive indirect effect of LKM on social entrepreneurship intentions via compassion increased significantly with the increasing level of entrepreneurship resilience such as, at $-1 \mathrm{SD}(\beta=0.12$, $\mathrm{LL}=0.193$, and $\mathrm{UL}=0.345)$, at mean $(\beta=0.354, \mathrm{LL}=0.283$, and $\mathrm{UL}=0.426)$, and at $+1 \mathrm{SD}(\beta=0.440, \mathrm{LL}=0.350$, and $\mathrm{UL}=0.535)$ as shown in the Table 13. On the basis of the above mentioned results, hypothesis 5 was fully supported and accepted, i.e., the moderated mediated effect of LKM on social entrepreneurship intentions, via compassion.

Entrepreneurship resilience strengthened the positive relationship between compassion and social entrepreneurship. We explored the moderating effect in a graph in Figure 5, which exposed that there was a positive relationship between entrepreneurship resilience and social entrepreneurship and this positive relationship between entrepreneurship resilience and social entrepreneurship was stronger when relative coworker support was at a higher level than when it was at a lower level. Thus, hypothesis 6 was well supported. 


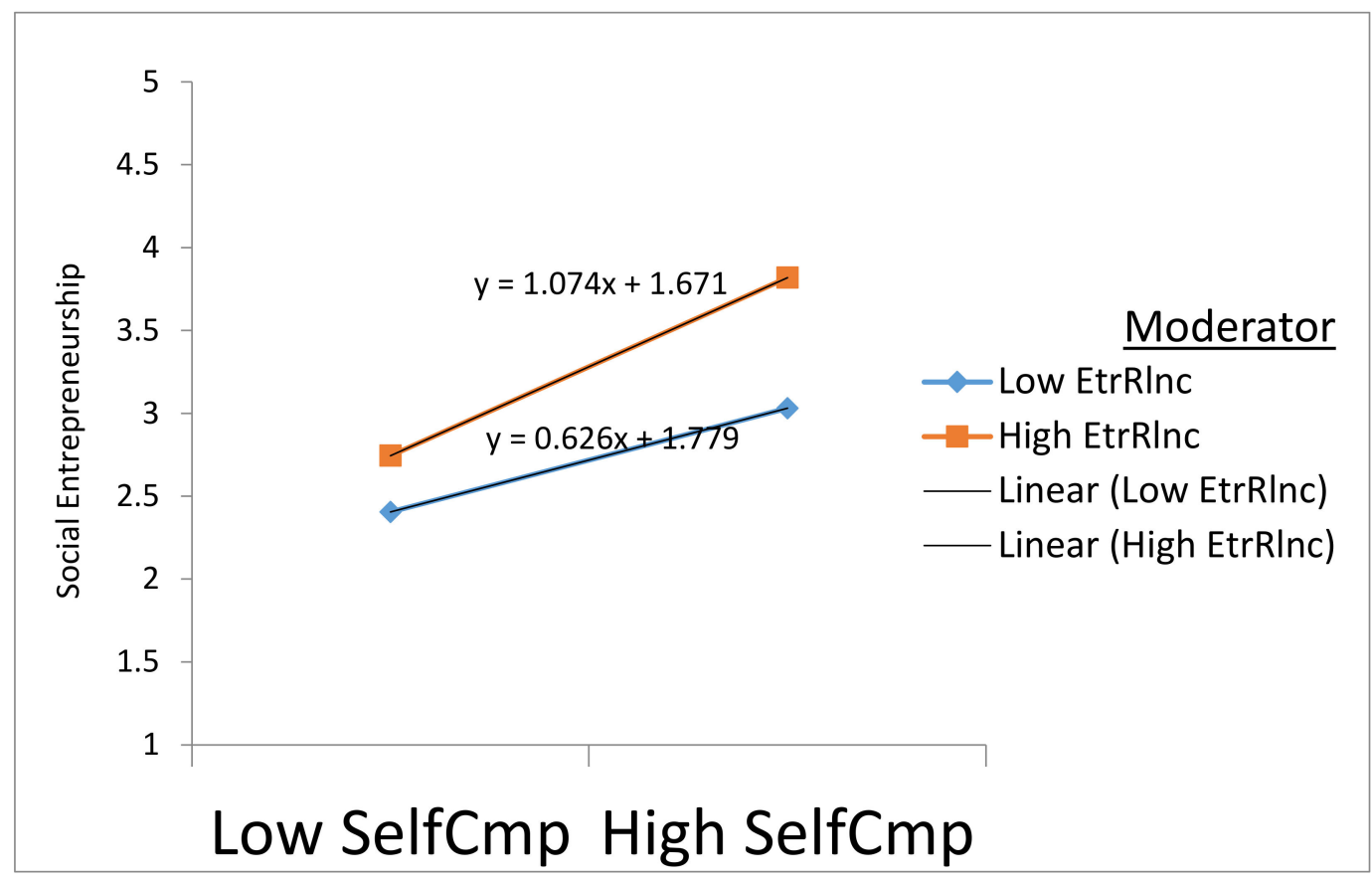

Figure 5. Interaction moderation.

\section{Discussion and Conclusions}

LKM remains as a measure of collective meditation practices originating from Islamic tradition and teaching. Compassion is central in Islam. Compassion is extremely more dominant in Islam after believing in one Allah and the Last Prophet Hazrat Muhammad (PBUH). In reality, compassion signifies the true essence of Islam and compassion is very significant in Islamic instructions than something else after believing the unity of God (Towhead) and Risalah (Messengership of Muhammad PBUH). There are definite words in the Holy Quran that stand as significantly focused, four of which are very often repeated, i.e., rahmah (compassion), adl (justice), ihsan (benevolence), and hikmah (wisdom).

The result of this study highlights that LKM motivated persons toward social entrepreneurship with the help of their compassion thoughtfulness, and this motivation will be at a high level if such a person also has the trait of entrepreneurship resilience. The first hypothesis of this study was accepted, which claimed that LKM has a direct positive relationship with compassion, which is consistent with the studies of [11]. It was also highlighted in the results that there was a direct positive significant relationship between LKM and compassion and the model fit also proved that tested compassion was a mediator between LKM and social entrepreneurship. This process of LKM towards compassion is just to satisfy some social and economic needs of self, others, and society. In doing this, compassion functioned as the original motivational instrument, with the help of LKM being decoded into social entrepreneurship intentions. The second hypothesis of the study claimed that compassion is a direct positive relation with the social entrepreneurship, which is also consistent with the findings of the studies of [11]. One notable thing in the results of study is that the direct positive impact of LKM on social entrepreneurship (0.033) was insignificant and the indirect relationship of LKM with social entrepreneurship via compassion (0.3641) was significant and positive, it means that compassion was fully mediated in the model of our study. This shows that LKM did not directly control social entrepreneurship intentions, besides LKM indirectly controlled compassion to social entrepreneurship intentions. These above mentioned studies that show a significant relationship between LKM and social entrepreneurship are in the context of other countries but our study shows an insignificant relationship between LKM and social entrepreneurship that is conducted with culture included. Data were gathered from 
the students where the context, culture, and background of the students were entirely different from the other countries. This relationship was not significant because students even having the emotions of LKM had no intentions for social entrepreneurship because they had their own personal problems, most of the students had their family and financial problems due to which they were bound to do a job to earn money instead of solving the social problems of society and having social entrepreneurship. Based on the contextual differences, poverty problems, unemployment, and highly expensive higher education the students tend to have jobs instead of having social entrepreneurship, which is why there was no significant relationship found between LKM and social entrepreneurship. Lastly the results of this study supported that entrepreneurship resilience mechanics were stronger than the mediation effect of compassion on the relationship between LKM and social entrepreneurship. The results of this study were very much consistent with the findings of several studies like [10,52], which acknowledged that the resilience ability of a person worked as a significant factor related with frequent entrepreneurship results, like entrepreneurial manners, intents, and interests, moreover resilience is a personal ability to handle the failure situations of an entrepreneurship. Moderation of resilience is significant in this study. This study proved that the entrepreneurship resilience was stronger the relationship between the compassion and social entrepreneurship and between the indirect relationship of LKM and social entrepreneurship via compassion.

The model of this study was also supported by the "ethics of care" theory. Care ethics is defined as "a species of activity that includes everything we do to maintain, contain, and repair our 'world' so that we can live in it as well as possible" [43]. On the notion of this theory, our model also expressed that only those persons having LKM and compassionate feelings, which are purely based on ethics of care, can be turned towards social entrepreneurship, in contrast persons who do not have the ethics of care in them cannot be motivated towards social entrepreneurship. Social entrepreneurship means the entrepreneurial process with the objective of satisfying some social mission, so it is proposed that social entrepreneurs execute the social entrepreneurship on the grounds of care for other, because they realize the responsibility of taking care of others and giving them due care [3]. On these grounds, it may be stated that care ethics pursue persons toward social entrepreneurship.

\subsection{Implication}

\subsubsection{Practical Implications}

The findings of this study with a practical perspective suggest that the persons who have the emotions of LKM and compassion can satisfy their emotions by way of formation of social entrepreneurship. The persons in a particular community that have the emotions of LKM and compassion, also have a thrill of solving the economic and social problems of others that can satisfy and fulfil their desire by commencing social entrepreneurship; through this social entrepreneurship undertaking they can solve particular social and economic issues of their society and satisfy their emotions. As there is already a major problem of unemployment that exists, to address this problem the model of this study suggests for students of business and management sciences that have the emotions of LKM and compassion could start at their societal places social entrepreneurship, so it provides them an opportunity to do their own undertakings, i.e., social entrepreneurship, and they can solve the financial and social problems of others.

For the purpose of entrepreneurial education and training, this model of LKM delivers practical suggestions. This study model could contribute practically in the field of entrepreneurial education, the students/persons who are prosocial and have positive emotions, entrepreneurial resilience, government support, and entrepreneurship education and training make it feasible with regard to social entrepreneurship. While in the entrepreneurship education and training process students may be familiarized with the obstacles or challenges they may have to face [23] in order to create the traits of resilience in themselves to meet the unexpected or failure result in social entrepreneurship. 
Another implication and practical contribution of this study was the key role of resilience towards social entrepreneurship. Social entrepreneurship is not such an easy task, especially since it is a difficult task to bring all the participants on one page regarding decisions, issues, disharmony, disputes, and stress. So, it is humbly suggested for higher educational institutes especially for business and management sciences to add in their academic schemes the resilience trait and the role of resilience in undertaking especially in entrepreneurship, so that the resilience trait may be strengthened or developed in the students of business and management sciences.

This study also had some public policy and community implementations as shown in the Figure 6. For public policy it is suggested by this study that some incentives, reliefs, and tax exemptions may be formulated in such a type of undertakings that comes under the jurisdictions of social entrepreneurship in order to enhance motivation among communities towards social entrepreneurships, so that communities may solve their economic, financial, and social problems on their own rather than looking for government or other employers for employment opportunities. Unemployment is one of the biggest and most serious problems, this unemployment problem can be addressed through public policy regarding undertakings of social entrepreneurships giving some incentives, reliefs, and tax exemptions, so that the communities can take initiatives to avail the incentives and reliefs to overcome their economic and social problems and employ themselves on their own.

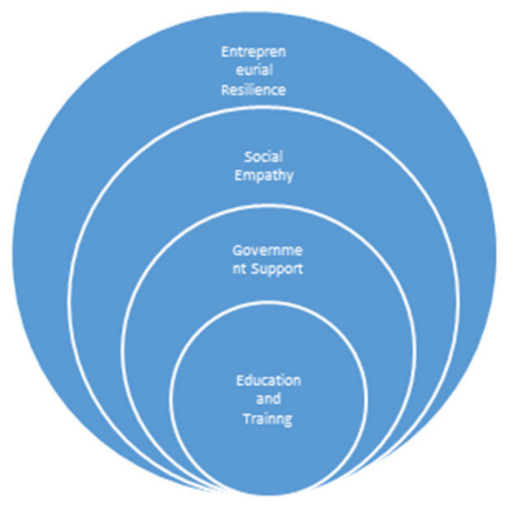

Figure 6. Practical implication.

\subsubsection{Theoretical Implication}

The model of this study advanced a vital contribution in the literature of LKM, compassion, entrepreneurship resilience, and social entrepreneurship. Social entrepreneurship comes from compassion [4], but it has not been discussed that compassion is directed by LKM, so our study contributed to the literature that LKM acts as a driver of compassion, which identified the intentions towards social entrepreneurship.

The findings of this study also open opportunities for research scholars to contribute their research in the way how prosocial persons can satisfy their emotions while keeping their financial and social concerns. This study develops the understanding in how some antecedents and prosocial behavior of persons like LKM, compassion, and resilience play a vital role for enhancing the social entrepreneurship intentions, this understanding will open new horizons for researchers in the field of social entrepreneurship.

While deep insights about LKM and compassion for social entrepreneurship decisions as a foundation of effective behavior, this effective behavior was extended in this study by adding a moderating role of entrepreneurship resilience as a further variable in order to examine the impact of LKM and compassion on social entrepreneurship with the conditional effect of entrepreneurship resilience. Already there is several research that has been done on the entrepreneurship and compassion relationship but no study has been conducted to understand the entrepreneurs' compassion as a facilitator or as a mediator towards the relationship between LKM and social entrepreneurship so this understanding was developed through this study, this is also a great contribution in the theoretical perspective. 
Through this study the compassion mediation towards social entrepreneurship was highlighted, which provides a new insight for the academia of entrepreneurship. Ignoring the interests and area of research, the relationship between LKM and compassion is also highly valuable for scholars and for research in the field of social entrepreneurship. LKM and compassion are the psychological emotions that can be satisfied through the completion of social entrepreneurship ventures, these psychological emotions can be a great scenario for researchers of entrepreneurship.

According to the findings of this study, the model indicates clearly that in social entrepreneurship intentions, resilience plays an essential role. Our findings reflect that the psychological personality trait of entrepreneurial resilience considered in this model led to enhancement in both social entrepreneurship intentions and motivation towards doing it to satisfy his/her emotions, i.e., LKM and compassion. The most important thing in our model was resilience, especially the personality trait of a person who is able to cope with difficulties and able to find some creative solution in the case of problems/difficulties/failures. So, resilience in this model as a moderator in the direct relationship between compassion and social entrepreneurship and in the indirect relationship between LKM and social entrepreneurship via compassion had a vital contribution to the literature of social entrepreneurship and more importantly in the literature of resilience.

So, the two variables of this study, LKM and compassion, are based on the essence of the theory of "ethics of care". This is a novel study of social entrepreneurship intentions, in which those feelings/emotions were proved to be the drivers of social entrepreneurship intentions, these feelings are based on the ethics of care theory, which is a novel and vital contribution to the literature of social entrepreneurship.

\subsection{Limitations and Future Directions}

This study has so many practical implications and theoretical contributions but it is not free from limitations. The first limitation is with respect to samples, this study selected students of business and management studies and the students may not be well aware of actual and practical situations regarding emotions, resilience, and social entrepreneurship. Instead of students the samples that may be selected should be entrepreneurs, which may produce better actual results regarding social entrepreneurship.

This study was conducted and manipulated with some serious economic and social problems like unemployment, poverty, economic conditions, necessity items crises, etc. A bitter reality, if not discussed here then it may be an injustice, is that majority of the students belong to poor families that can hardly afford their academic expenses with the hope that after completing their education they will get a good employment opportunity and will provide financial assistance to their families, and so student and their families cannot have financial resources to invest in social entrepreneurship. So, in this scenario, the students although they have the LKM, compassionate emotions, and resilience traits, they cannot have social entrepreneurship intentions due to the financial resources/capital constraints. So, this is a big and serious limitation that lies with this study. Due to the existence of such problems, it is suggested for future research that future studies be conducted with the context of any other country that might not have such a problem.

Another limitation of the study is that we measured the LKM, compassion, and resilience about the respondent's self while social entrepreneurship is a process of working with other people in society, so one individual who is interested in social entrepreneurship has to include other people in society so there is also a need to know the emotions and traits of other people who are included in the formation of social entrepreneurship. It is suggested for future researchers that data may be collected to form a group of persons who are interested in social entrepreneurship rather than individuals. For support of the theoretical framework, we applied the theory "ethics of care", this theory fully supported our model. However, for the future researchers, it is recommended that they use any other theory relating to human resources especially relating with entrepreneurship that can be used for the support of the model based on social entrepreneurship. 
The next limitation of this study is that all the variables for which data was collected were of a positive nature of personality emotions and traits through which the respondents may be biased while responding to the questionnaire, i.e., LKM, compassion, resilience, and social entrepreneurship, all four of these variables are of a positive nature for which there may be chances of biased responses. To overcome this limitation, we suggest for future research of social entrepreneurship to include in their studies any one of the variables that are negative in nature like anger, risk avoider, indecisive, insincere, abusive, etc., so that biasness of the respondent may be avoided for accurate and generalized results.

\subsection{Conclusions}

In this study we specifically deliberated some personality traits that boost the intentions towards social entrepreneurships. These personality traits were LKM, compassion, and entrepreneurship resilience, these personality traits interacted with each other in this study to enhance social entrepreneurship intentions. It was proven in this study that LKM motivated the persons towards social entrepreneurship with the help of their compassion quality, and this motivation will be at a high level if such a person also has the trait of entrepreneurship resilience. The most important thing in this study is resilience, especially the personality trait of a persons who is able to cope with difficulties and able to find some creative solution in the case of problems/difficulties/failures of social entrepreneurship. On the notion of "ethics of care" theory, our study also expressed that only those persons having LKM and a compassionate feeling, which are purely based on ethics of care, could be turned towards social entrepreneurship. The persons in a particular community that have the emotions of LKM and compassion, also have a thrill of solving the economic and social problems of others, which can satisfy and fulfil their desire by commencing social entrepreneurship; through this social entrepreneurship undertaking they can solve particular social and economic issues of their society and satisfy their emotions. This study specifically addressed one of the biggest problem, the unemployment problem, for the government, it is suggested by this study that some incentives, reliefs, and tax exemptions may be formulated in such type of undertakings that comes under the jurisdictions of social entrepreneurship in order to enhance motivation among the communities towards social entrepreneurships, so that communities may solve their economic, financial, and social problems on their own rather than looking for government or other employers for employment opportunities. However, one grave problem remains, majority of the students belong to poor families, which hardly afford their academic expenses just on the hope that after completing their education, they will get a good job and they will provide financial assistance to their families, and the student and their families do not have such financial resources to invest in social entrepreneurship. So, in this scenario, although the students have the LKM, compassionate emotions, and resilience traits, they cannot have social entrepreneurship intentions due to financial resources/capital constraints.

Author Contributions: Conceptualization, H.A.S. and S.Z.; methodology, W.M.A.-R.; software, S.Z.; validation, A.S.A.-A. and A.R.A. formal analysis, investigation, resources, A.S.A.-A. and A.R.A.; data curation, writing—original draft preparation, writing—review and editing, H.A.S.; W.M.A.-R. visualization, supervision, project administration, S.Z.; formal analysis and methodology, S.A. All authors have read and agreed to the published version of the manuscript.

Funding: This work was funded by the Researcher Supporting Project, Qassim University, Ar Rass, Saudi Arabia.

Institutional Review Board Statement: Not applicable.

Informed Consent Statement: Not applicable.

Data Availability Statement: Not applicable.

Conflicts of Interest: The authors declare no conflict of interest. 


\section{References}

1. André, K.; Pache, A.C. From Caring Entrepreneur to Caring Enterprise: Addressing the Ethical Challenges of Scaling up Social Enterprises. J. Bus. Ethics 2016, 133, 659-675. [CrossRef]

2. Mair, J.; Martí, I. Social entrepreneurship research: A source of explanation, prediction, and delight. J. World Bus. 2006, 41, 36-44. [CrossRef]

3. Doherty, B.; Haugh, H.; Lyon, F. Social enterprises as hybrid organizations: A review and research agenda. Int. J. Manag. Rev. 2014, 16, 417-436. [CrossRef]

4. Sud, M.; Van Sandt, C.V.; Baugous, A.M. Social Entrepreneurship: The Role of Institutions. J. Bus. Ethics 2009, 85, 201-216. [CrossRef]

5. Guia, J. How Does Compassion Affect the Actions of Entrepreneurs Prior to Establishing the Social Enterprise? In Proceedings of the DLSU Research Congress 2017, Manila, Philippine, 20 June 2017.

6. Medyanik, O.; Al-Jawni, F. An Investigation of Students' Social Entrepreneurial Intentions in Syria: An Empirical Test. In Modernizing Academic Teaching and Research in Business and Economics; Marx Gómez, J., Aboujaoude, M., Feghali, K., Mahmoud, T., Eds.; Springer: Cham, Switzerland, 2017. [CrossRef]

7. Hu, X.; Marlow, S.; Zimmermann, A.; Martin, L.; Frank, R. Understanding Opportunities in Social Entrepreneurship: A Critical Realist Abstraction. Entrep. Theory Pract. 2020, 44, 1032-1056. [CrossRef]

8. Hanson, S.K.; Hessel, H.M.; Danes, S.M. Relational processes in family entrepreneurial culture and resilience across generations. J. Fam. Bus. Strategy 2019, 10, 100263. [CrossRef]

9. Canestrino, R.; Ćwiklicki, M.; Magliocca, P.; Pawełek, B. Understanding social entrepreneurship: A cultural perspective in business research. J. Bus. Res. 2020, 110, 132-143. [CrossRef]

10. Saebi, T.; Foss, N.J.; Linder, S. Social Entrepreneurship Research: Past Achievements and Future Promises. J. Manag. 2019, 45, 70-95. [CrossRef]

11. Kimmitt, J.; Muñoz, P. Sensemaking the 'social' in social entrepreneurship. Int. Small Bus. J. 2018, 36, 859-886. [CrossRef]

12. Korber, S.; McNaughton, R.B. Resilience and entrepreneurship: A systematic literature review. Int. J. Entrep. Behav. Res. 2018, 24, 1129-1154. [CrossRef]

13. Hermelin, B.; Rusten, G. A place-based approach to social entrepreneurship for social integration-Cases from Norway and Sweden. Local Econ. 2018, 33, 367-383. [CrossRef]

14. Hofmann, S.G.; Grossman, P.; Hinton, D.E. Loving-kindness and compassion meditation: Potential for psychological interventions. Clin. Psychol. Rev. 2011, 31, 1126-1132. [CrossRef]

15. Jeremy, C.; Todd, S.; Moss, W.; Lumpkin, G.T. Research in Social Entrepreneurship: Past Contributions and Future Opportunities. Strateg. Entrep. J. 2009, 3, 161-194.

16. Figley, C.R. Compassion Fatigue as Secondary Traumatic Stress Disorder: An Overview; Brunner/Mazel Psychological Stress Series, No. 23; Routledge Taylor\&Francis Group: London, UK, 1995; pp. 13-14.

17. Miller, T.L.; Grimes, M.G.; Mcmullen, J.S.; Vogus, T.J. Venturing for others with heart and head: How compassion encourages social entrepreneurship. Acad. Manag. Rev. 2012, 37, 616-640. [CrossRef]

18. Muhamad, S.; Rashid, N.K.A.; Hussain, N.E.; Akhir, N.H.M.; Ahmat, N. Resilience as a moderator of government and family support in explaining entrepreneurial interest and readiness among single mothers. J. Bus. Ventur. Insights 2020, 13 , e00157. [CrossRef]

19. Galante, J.; Galante, I.; Bekkers, M.J.; Gallacher, J. Effect of kindness-based meditation on health and well-being: A systematic review and meta-analysis. J. Consult Clin. Psychol. 2014, 82, 1101-1114. [CrossRef]

20. Fredrickson, B.L.; Cohn, M.A.; Coffey, K.A.; Pek, J.; Finkel, S.M. Open hearts build lives: Positive emotions, induced through loving-kindness meditation, build consequential personal resources. J. Pers. Soc. Psychol. 2008, 95, 1045-1062. [CrossRef] [PubMed]

21. Vlasov, M.; Bonnedahl, K.J.; Vincze, Z. Entrepreneurship for resilience: Embeddedness in place and in trans-local grassroots networks. J. Enterprising Communities 2018, 12, 374-394. [CrossRef]

22. Wiklund, J.; Nikolaev, B.; Shir, N.; Foo, M.D.; Bradley, S. Entrepreneurship and well-being: Past, present, and future. J. Bus. Ventur. 2019, 34, 579-588. [CrossRef]

23. Engel, Y.; Noordijk, S.; Spoelder, A.; van Gelderen, M. Self-Compassion When Coping with Venture Obstacles: Loving-Kindness Meditation and Entrepreneurial Fear of Failure. Entrep. Theory Pract. 2021, 45, 263-290. [CrossRef]

24. Mair, J.; Noboa, E. Social Entrepreneurship: How Intentions to Create a Social Venture are Formed. In Social Entrepreneurship; Mair, J., Robinson, J., Hockerts, K., Eds.; Palgrave Macmillan: London, UK, 2006. [CrossRef]

25. Althunibat, A.; Binsawad, M.; Almaiah, M.A.; Almomani, O.; Alsaaidah, A.; Al-Rahmi, W.; Seliaman, M.E. Sustainable Applications of Smart-Government Services: A Model to Understand Smart-Government Adoption. Sustainability 2021, 13, 3028. [CrossRef]

26. Austin, J.; Stevenson, H.; Wei-Skillern, J. Social and Commercial Entrepreneurship: Same, Different, or Both? Entrep. Theory Pr. 2006, 30, 1-22. [CrossRef]

27. Islam, S.M. Towards an integrative definition of scaling social impact in social enterprises. J. Bus. Ventur. Insights 2020. [CrossRef]

28. Santos, F.M. A Positive Theory of Social Entrepreneurship. J. Bus. Ethics 2012, 111, 335-351. [CrossRef] 
29. Weng, H.Y.; Fox, A.S.; Shackman, A.J.; Stodola, D.E.; Caldwell, J.Z.; Olson, M.C.; Rogers, G.M.; Davidson, R.J. Compassion training alters altruism and neural responses to suffering. Psychol. Sci. 2013, 24, 1171-1180. [CrossRef]

30. Chadwick, I.C.; Raver, J.L. Psychological Resilience and Its Downstream Effects for Business Survival in Nascent Entrepreneurship. Entrep. Theory Pract. 2020, 44, 233-255. [CrossRef]

31. Dees, B.G.; Anderson, B.B.; Wei-Skillern, J. Strategies for spreading social innovations. Stanf. Soc. Innov. Rev. 2004, 1, $24-32$.

32. Logie, K.; Frewen, P. Self/Other Referential Processing Following Mindfulness and Loving-Kindness Meditation. Mindfulness 2015, 6, 778-787. [CrossRef]

33. Palacios-Marqués, D.; García, M.G.; Sánchez, M.M.; Mari, M.P.A. Social entrepreneurship and organizational performance: A study of the mediating role of distinctive competencies in marketing. J. Bus. Res. 2019, 101, 426-432. [CrossRef]

34. Van Lange, P.A.; Gallucci, M.; Karremans, J.C.; Klapwijk, A.; Folmer, C.R. A social interaction analysis of empathy and fairness. Novartis Found Symp. 2007, 278, 97-221. [PubMed]

35. Engel, Y.; Kaandorp, M.; Elfring, T. Toward a dynamic process model of entrepreneurial networking under uncertainty. J. Bus. Ventur. 2017. [CrossRef]

36. Engert, V.; Kok, B.E.; Papassotiriou, I.; Chrousos, G.P.; Singer, T. Specific reduction in cortisol stress reactivity after social but not attention-based mental training. Sci. Adv. 2017, 3, e1700495. [CrossRef]

37. Weibel, D.T.; McClintock, A.S.; Anderson, T. Does Loving-Kindness Meditation Reduce Anxiety? Results from a Randomized Controlled Trial. Mindfulness 2017, 8, 565-571. [CrossRef]

38. McSweeney, M.J. Returning the 'social' to social entrepreneurship: Future possibilities of critically exploring sport for development and peace and social entrepreneurship. Int. Rev. Sociol. Sport 2020, 55, 3-21. [CrossRef]

39. Sassmannshausen, S.P.; Volkmann, C. A Bibliometric Based Review on Social Entrepreneurship and Its Establishment as a Field of Research; Schumpeter Discussion Papers; Crapelet Parisl: Wuppertal, Germany, 2013.

40. Wamsler, C.; Brossmann, J.; Hendersson, H.; Kristjansdottir, R.; McDonald, C.; Scarampi, P. Mindfulness in sustainability science, practice, and teaching. Sustain. Sci. 2018, 13, 143-162. [CrossRef]

41. Littlewood, D.; Holt, D. Social Entrepreneurship in South Africa: Exploring the Influence of Environment. Bus. Soc. 2018, 57, 525-561. [CrossRef]

42. Zulfiqar, S.; Nadeem, M.A.; Khan, M.K.; Anwar, M.A.; Iqbal, M.B.; Asmi, F. Opportunity Recognition Behavior and Readiness of Youth for Social Entrepreneurship. Entre. Rsearch J. 2019. [CrossRef]

43. Harris, J.D.; Sapienza, H.J.; Bowie, N.E. Ethics and entrepreneurship. J. Bus. Ventur. 2009, 24, 407-418. [CrossRef]

44. Epitropaki, O.; Sy, T.; Martin, R.; Tram-Quon, S.; Topakas, A. Implicit Leadership and Followership Theories 'in the wild': Taking stock of information-processing approaches to leadership and followership in organizational settings. Lead. Q. 2013. [CrossRef]

45. Turker, D.; Selcuk, S.S. Which factors affect entrepreneurial intention of university students? J. Eur. Ind. Train. 2009, 33, 142-159. [CrossRef]

46. Gugi, J.K.; Gakure, R.W.; Waithaka, S.M.; Kiwara, A.N. Application of Shapero's Model In Explaining Entrepreneurial Intentions Among University Students In Kenya. Int. J. Bus. Soc. Res. 2013, 2, 125-148.

47. Ariyabuddhiphongs, V.; Pratchawittayagorn, A. Peace of mind and organizational citizenship behavior: The mediating effect of loving kindness. Arch. Psychol. Relig. 2014, 36, 233-252. [CrossRef]

48. Oveis, C.; Horberg, E.J.; Keltner, D. Compassion, Pride, and Social Intuitions of Self-Other Similarity. J. Pers. Soc. Psychol. 2010, 98, 618-630. [CrossRef]

49. Sinclair, V.G.; Wallston, K.A. The development and psychometric evaluation of the Brief Resilient Coping Scale. Assessment 2004, 11, 94-101. [CrossRef]

50. Anderson, J.C.; Gerbing, D.W. Structural Equation Modeling in Practice: A Review and Recommended Two-Step Approach. Psychol. Bull. 1988, 103, 411-423. [CrossRef]

51. Wiedemann, A.U.; Schuz, B.; Sniehotta, F.; Scholz, U.; Schwarzer, R. Disentangling the relation between intentions, planning, and behaviour: A moderated mediation analysis. Psychol. Health 2009. [CrossRef]

52. Miller, R.M. Academic Entrepreneurs, Public Policy, and the Growth of Latin American Studies in Britain during the Cold War. Lat. Am. Perspect. 2018, 45, 46-68. [CrossRef] 